633.1747

M363s

Arthur Martin. $\quad(c a .1970)$
The Story of Broomcorn. 
MLROAS heton!- anvy 


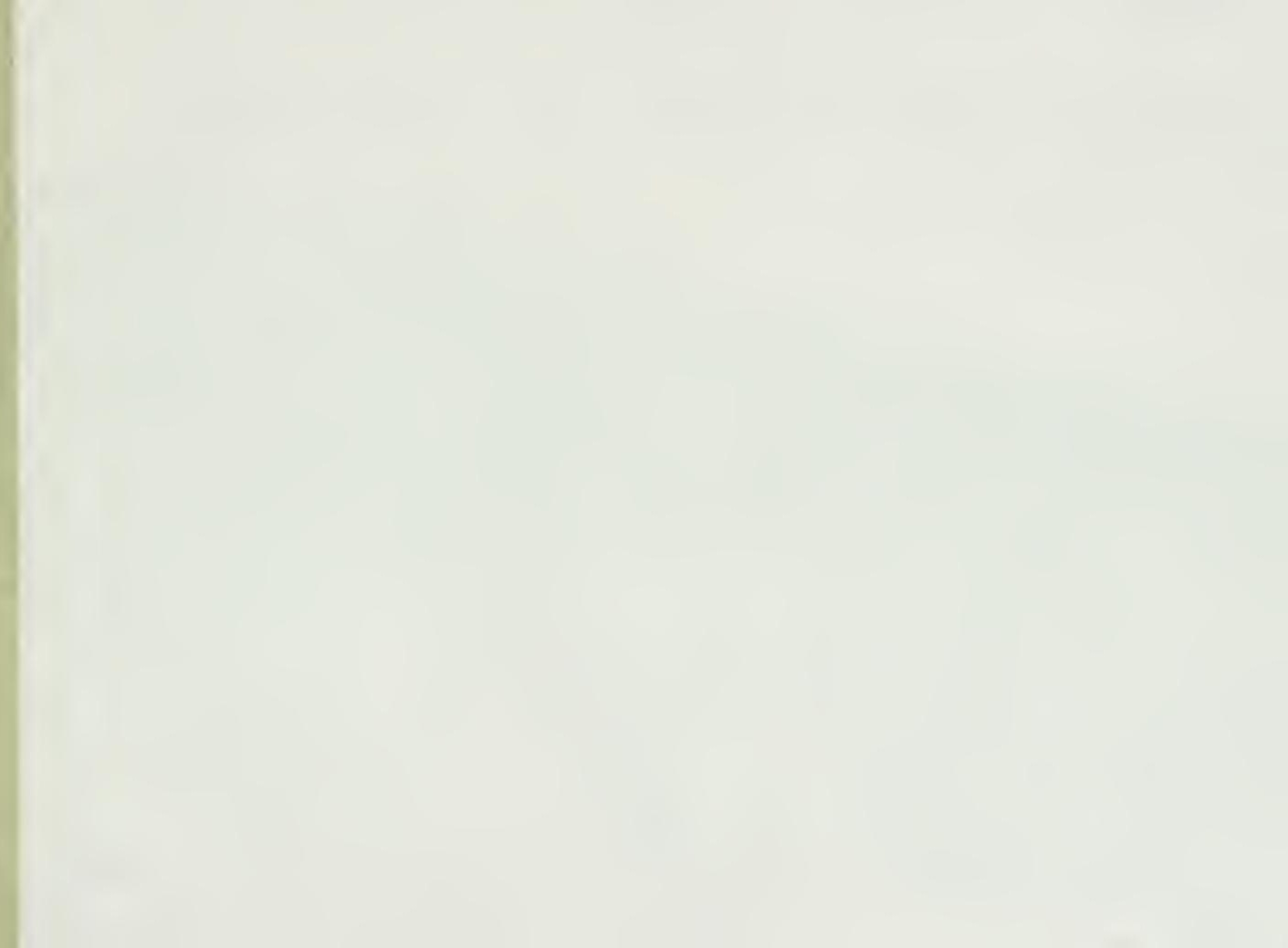



ILLINOIS HISTORICAL SURVEY 


\section{The Story of Broamearn}

0

$\mathrm{NE}$ of the most common things in all our life is the unpretentious broom, common in our lives as it was in the lives of our remote ancestors as well as the so-called savage tribes of the present day and in ancient times. Its shape, the material of which it is made and its use have changed through the centuries more than almost any other common article in our househo'dl. Yet in the eyes of the general public, how many know the material and manufacture of the article?

Because here in central Illinois you are near the location of the main source of broomcorn-Arcola being known as the broomcorn capital of Americait is appropriate we give a thought to broomcorn and brooms, both from a historical angle and the more practica! manufacturing standpoint.

The forerunners of the present clay broom were crude devices. One type used by early savage tribes was an article made by the tying of twigs or fibers to the end of a stick. Another was fashioned by a clever way of splitting a hickory stick about four feet long from the end to within a few inches of the other end and then wetting and bending these small splinters down and tying them in the form of a bundle. It was round in shape and varied in size as did the shape of its handle. For untold centuries such was the tool for removing trash. A finer brush than twigs, but made of different materials, was used in Europe and Asia. Only slight mention was ever made prior to 1790 to a form of sugar cane, with a longer head, whose native home was India.

The honor of introducing broomcorn to America goes to Benjamin Franklin-one of the great heroes of our history. The many things he did for America and his genius both in philosophy and inrention have, to my way of thinking, not been surrassed by any other American leader.

Near 1790 or shortly thereafter a friend of Franklin's traveling in Europe and Asia sent him a little brush the size of your hand which he found in his travels. Franklin used this to clean the dust from his travel-stained hat. To one of the straws of this brush clung a seed which Franklin's curiosity caused him to plant the following spring. A garden novelty resulted and for a few years this p'ant was an ornament to different Philadelphia gardens. Then about 1795 Levi Dickinson, an old bachelor living at North Hadley, Mass., got a handful of the seed and took it home to plant and that fall had enough straw to make thirty brooms. Because they were so much better than the old round 


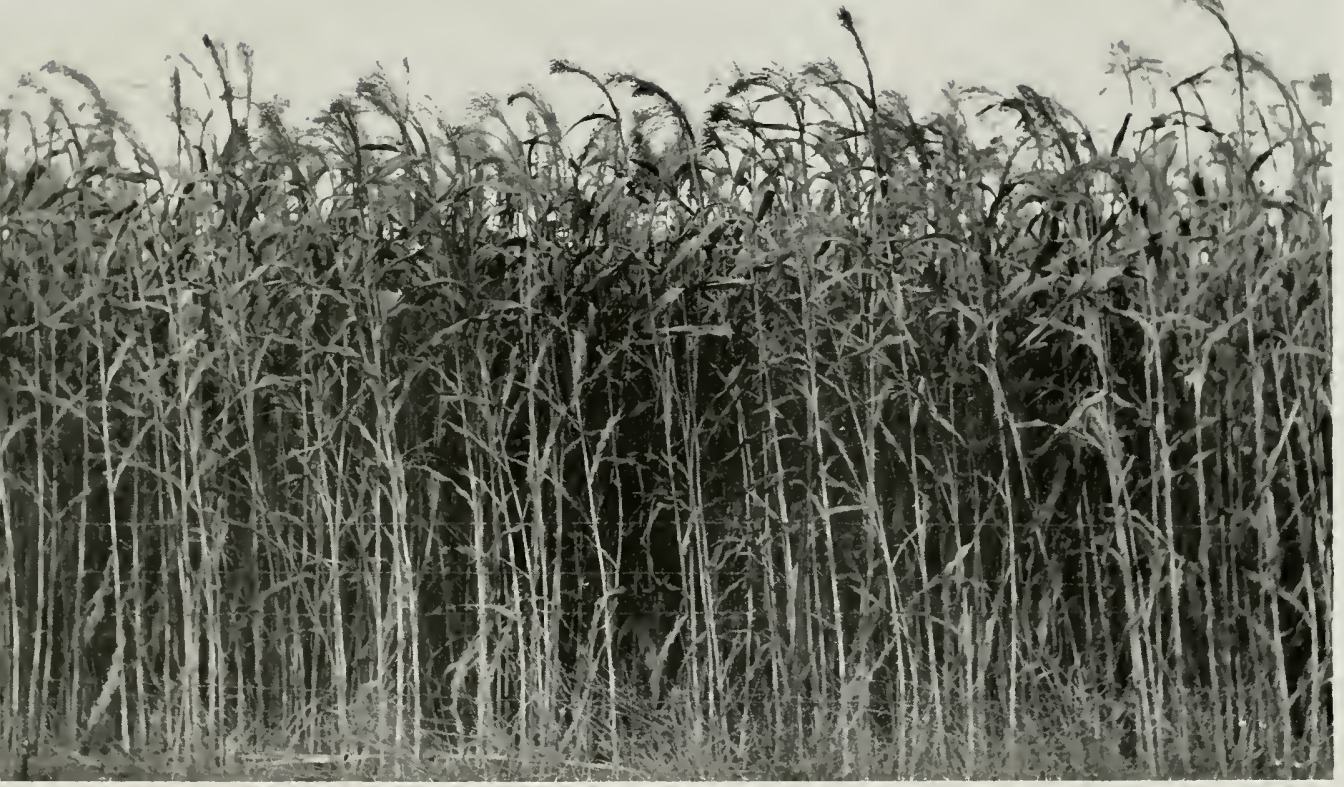

Illinois is one of the principal broomcorn producing states in the nation. Douglas, Coles and Cumberland counties grow most of the broomeorn in the state-at one time produced more than half of all the "brush" consumed in the United States. 


\section{The Stany of Braomearn}

hickory brooms they sold like hot cakes. By 1797 he planted a half acre and an acre the following year and in 1798 made between 100 and 200 brooms. His enthusiasm caused him to prophesy wonders for this industry as every year his production increased. By the start of the century neighbors of Dickinson, seeing his apparent prosperity, started to raise some of this coln and make it into brooms.

Then the Mohawk Valley of New York was found to raise so much better brush than Massachusetts that the crop migrated there and soon the manufacture of brushes was started there and for $y$ e a rs flourished. Here the Niskayuna Shakers went into both raising the brush and making it into brooms. Here also the brooms changed their shapes. Rougher corn was put on the inside, more of it put on two sides of the handle opposite e a ch other and the result was then flattened by a press to hold it in shape. This added to the broom's present streamlined appearance and to its sales volume as well. It was here the first machines were used to wind the wire around the handle and over the layers of fibre, thereby enabling a man to make several times the number of brooms he could tie by hand. Then migrating mankind carried the seed and idea to Ohio and Tennessee.

It was, however, in 1867 that John Cofer, al farmer living southeast of Arcola, visiting in Tennessee became interested in the plant and its uses.

Pictured here--open-sided shed for curing broomcorn after it has been cut.

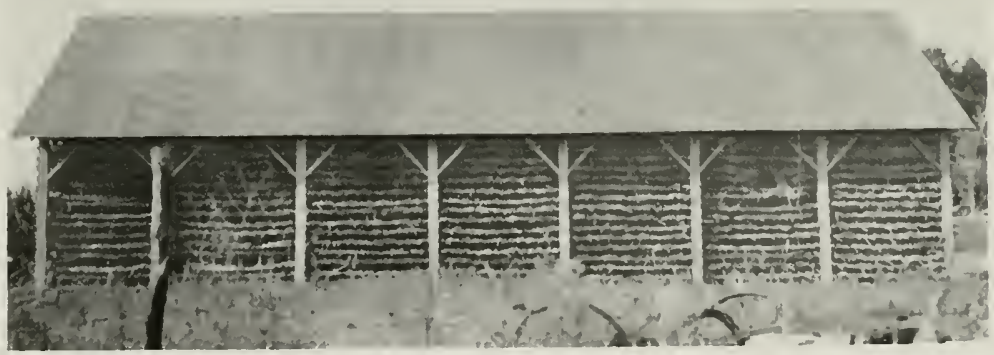

PAGE THREF 


\section{The Story of Broamearn}

He brought sereral bushels of seed back to Illinois and he and the neighbors planted it. The brush found a ready sale to some factories just opened in Chicago and the next few years saw a great increase in acreage because the soil and climate of Central Illinois produced the best brush known. Its acreage spread every direction from Arcola but mostly to the south.

Vision of fame and fortune in central Illinois were soon dimmed by the fact of limited demand and the headache of production. Soon it was found out that domestic and export demand could use only 50,000 ton per year, regardless of quality or price, and this amount holds true even to the present day despite the increase in population.

Machinery has made almost no headway in the harvesting of the crop although in the manufacture of brooms it has gone ahead considerably. Never has there been a machine made to take the place of hand labor in cutting, bunching, drying and bailing this crop, although thousands of dollars have been spent trying. One of the reasons, of course. is the limited prospective sales of such a machine or machines.

Broomcorn is planted in the same type of ground with the same equipment as Indian corn or sorghum cane. A bushel of seed will plant about 18 acres. It looks not unlike these plants in its growth. The tassel-the only part used-towers above the ground from eight to twelve feet and lucky is the man whose field grows to its maturity without a tangled mess here and there. The tangling of stalks involves a great deal of extra hand work at harvest time. It takes 90 dars, more or less, to mature a crop and it will mature on less moisture than Indian corn and will stand lots of wet weather if not too late in its growth. The tedious manual labor of harresting usually begins in September.

Walking backwards down the row, a man breaks the stalks first from one row and then another, laying each row on the opposite side forming a "table" three feet high with the "tassels" or" brush extending to the edge or near it. The cutting is done with a thick-bladed, large size knife and is done in such a way as to remove the head but to leave the boot or sheaf or blade on the stalk. A handful at a time cut and laid on the "table" awaits a team to haul it to the house for seeding and shedding. Seeding is done now by belt feeding and passing brush end through a twin rerolving cylinder whose teeth knock the seeds from the brush. Then the brush 


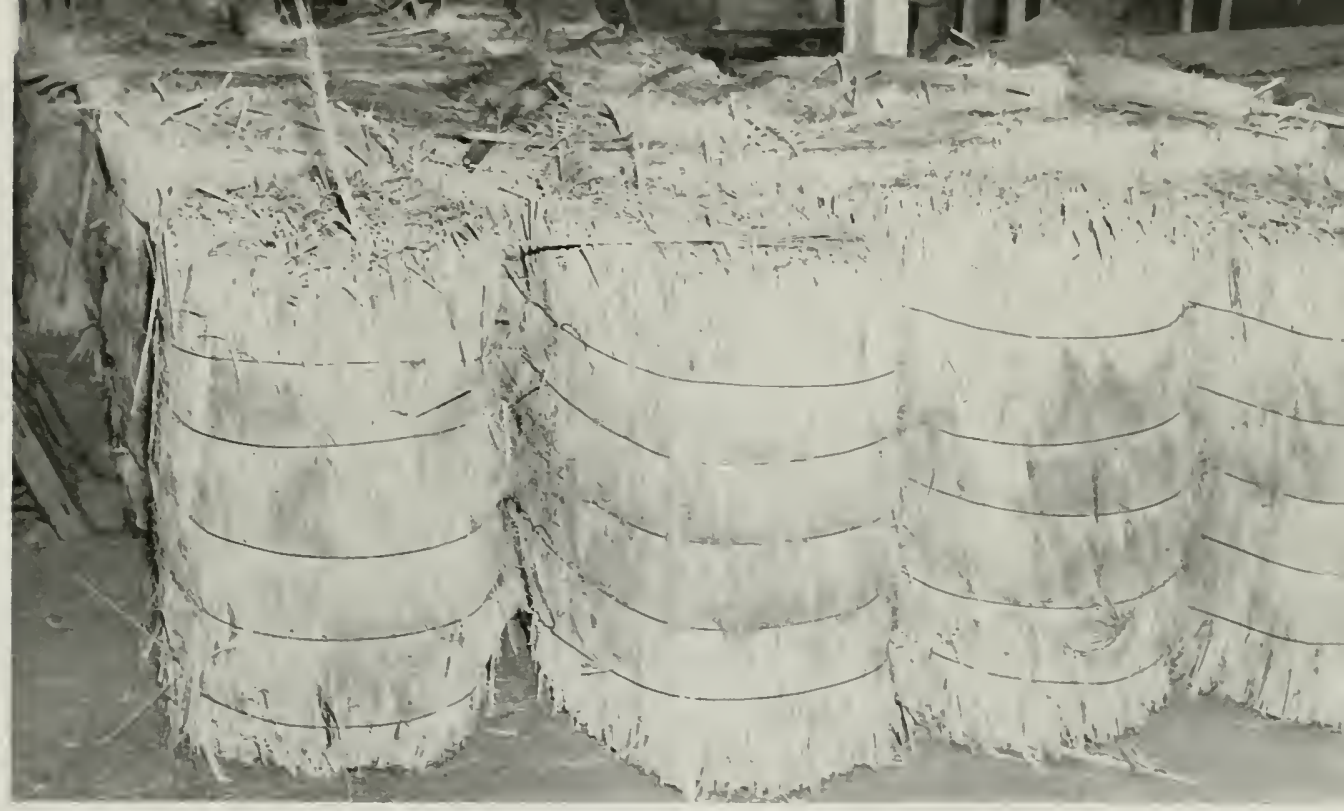

Broomcorn in the bale-the average bale weighs between 350 and 400 pounds. One ton of broomcorn will make about one thousand brooms. At current prices, the grower can realize about $\$ 300$ per ton, but higher labor costs cut the net profit. 


\section{The Stary of Braomearn}

has to be put in a shed for a few weeks to cure and dry. Remember, this is cut by hand, laid on table by hand and then picked up and put on special dump wagons by hand and again picked up at threshing site by hand, fed on belt, taken off belt and carried by armloads to the drying shed and scattered over slats. Then, and still by hand labor, comes the baling. By hand again this brush, which has been placed on these shelves a few weeks before, is taken off and laid in the baler and pressed into $300-$ 500 pound bale and is ready to sell. This labor once was done by large groups of migrating labor known as "canaries" or "johnnies" who filled the towns and countryside at cutting time, filled the saloons and also filed the countryside with fear. This was the way of harvesting and processing broomcorn for years. Then the farmer's' wives had to cook three meals for tein to forty hungry men, who slept in the barn. The "canaries" often collected their pay each day and spent their wages at night gambling and drinking. But of late years fields of corn have grown smaller and neighborhood helpers drive in, bringing their lunch. This eliminates a large amount of extra work. Harvesting is done on a piece work basis. As a result of this, Illinois does not raise the tonnage it used to but this is madeup by crops now in Oklahoma and some of the western states.

A "table" is two rows, 80 rods long (a quarter of a mile) and a common man cuts three tables a day while some experts get four or five. A dollar a table was once the regular price but lately price has been inflated to several times that, depending upon conditions of the crop. Seeding is done by the hour rate.

An Illinois crop averages a ton to three or four acres but out west it takes more acres. Sales of recent years have been all the way from $\$ 100.00$ to $\$ 500.00$ per ton.

Now we are ready to sell our crop. Buyers range the district to bid on the broomcorn much as in a horse trading marathon not mlike the swapping of articles in foreign countries. There is no board of tracle for the crop, very few standards are set, and there exists a wide variance of grade both needed and produced. There is no use for the corn except for brooms. There is no other substitute for the manufacturer to use; but the marketing of a crop is as unique as a tobaceo auction. Out west around Lindsay, Oklahoma, there is a custom whereby farmers often bring their crops to market and the streets are filled as buyers go from one to

PAGE SIX 


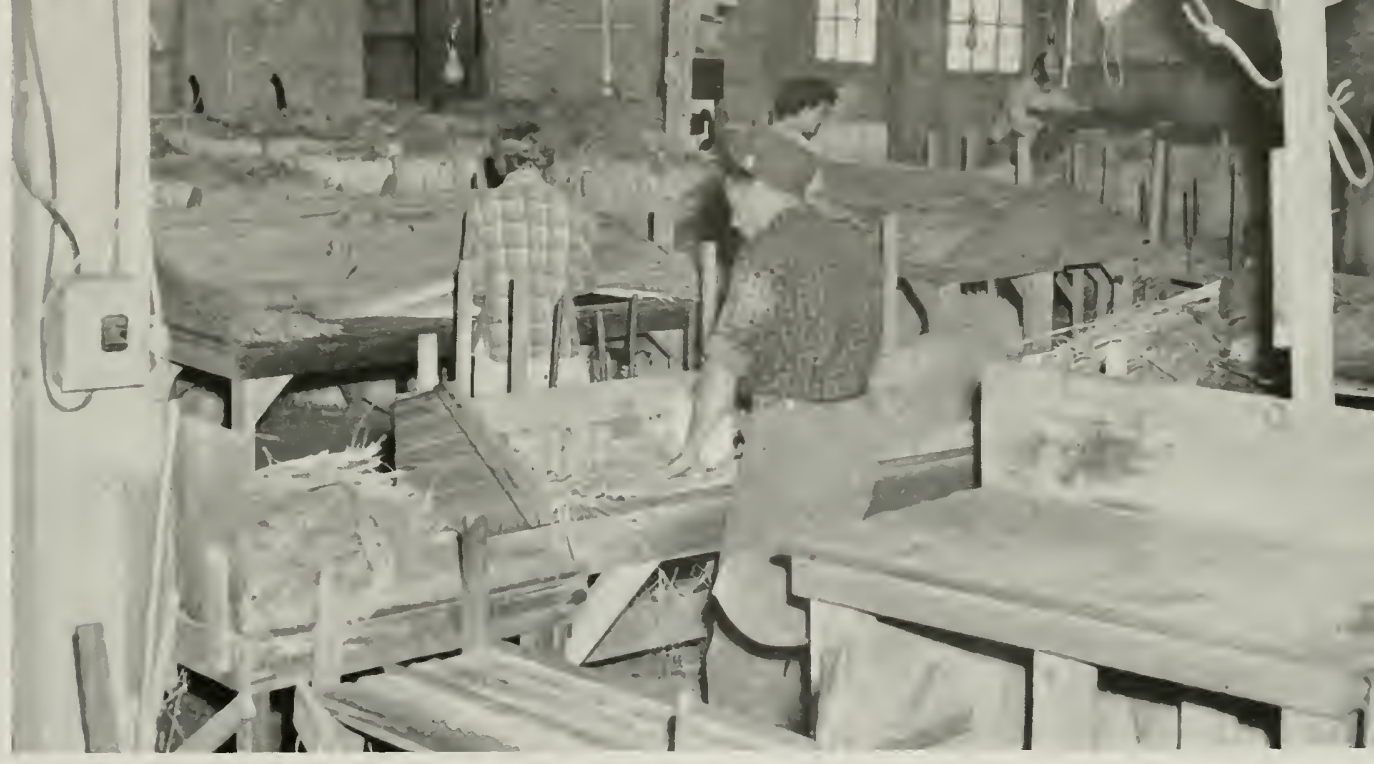

A scene in a broomcorn factory at Arcola; corn is sorted manually as to length, color and texture of fiber. The coarser fibers are used for industrial broomcorn, while the rest goes into house brooms or whisk brooms. 


\section{The Siary of Braomearn}

another sampling, trading, and finally buying.

The Nat'l. Broom Manufacturer's Association headquarters at Arcola, Illinois, has collected many interesting facts about the crop. About 1500 Illinois farmers grow broomcorn and five times that number in the west. There are approximately 2,000 broom factories in the United States, many of them being small affairs employing only one or two, while some of the larger factories equipped with modern machinery employ as many as two hundred people. Then there are the handle, twine and wire mills, so those regulariy employed within the industry number about 20,000 .

Fifty million brooms are produced annually in this country and as a ton of broomcorn makes about a thousand brooms, 50,000 tons are needed annually to supply the demand. These fifty million brooms sell for about $\$ 25,000,000.00$. This seems like small change when compared to government spendings of astronomical proportions, but still a sizeable sum as you and I figure our income tax returns. The sale of brooms has not increased in proportion to the increase in population since carpet sweepers, brushes and racuum cleaners do a lot of sweeping.

I have seen brooms sell all the way from $\$ 2.00$ per dozen to $\$ 18.00$ per dozen wholesale, but rest assured the well made broom will outwear several roor ones. There is no economy in the purchase of a broom built down to a price rather than up to a stanclard.

At last this crop of corn gets into the factory. Here first starts a process of sorting and grading. Stem by stem and often stalk by stalk each are put into a bundle for a specitic use. Then each bundle is dipped in a dye to get a uniform color and then in a bath of sulphur fumes orernight for bleaching. The next day more sorting and more grading ends up in several different piles decked at different places on the winding machine. Here a hardwood round handle is gripped close to the end by a machine which revolves as needed by operator. One end of wire under tension is inserted in the handle at exposed end first and then another grade of corn is held under wire and wrapped and fastened to the handle by wire. Extra corn on opposite side of handle in various ways forms the shoulders of your brooms and finally a cover of better, nicer corn is put on outside, spread evenly and neatly to make a good showing. The wire is then wrapped several layers thick and in various forms and by colored inserts makes the neat upper end of your brush and a nicer looking broom. The wire is then fastened 


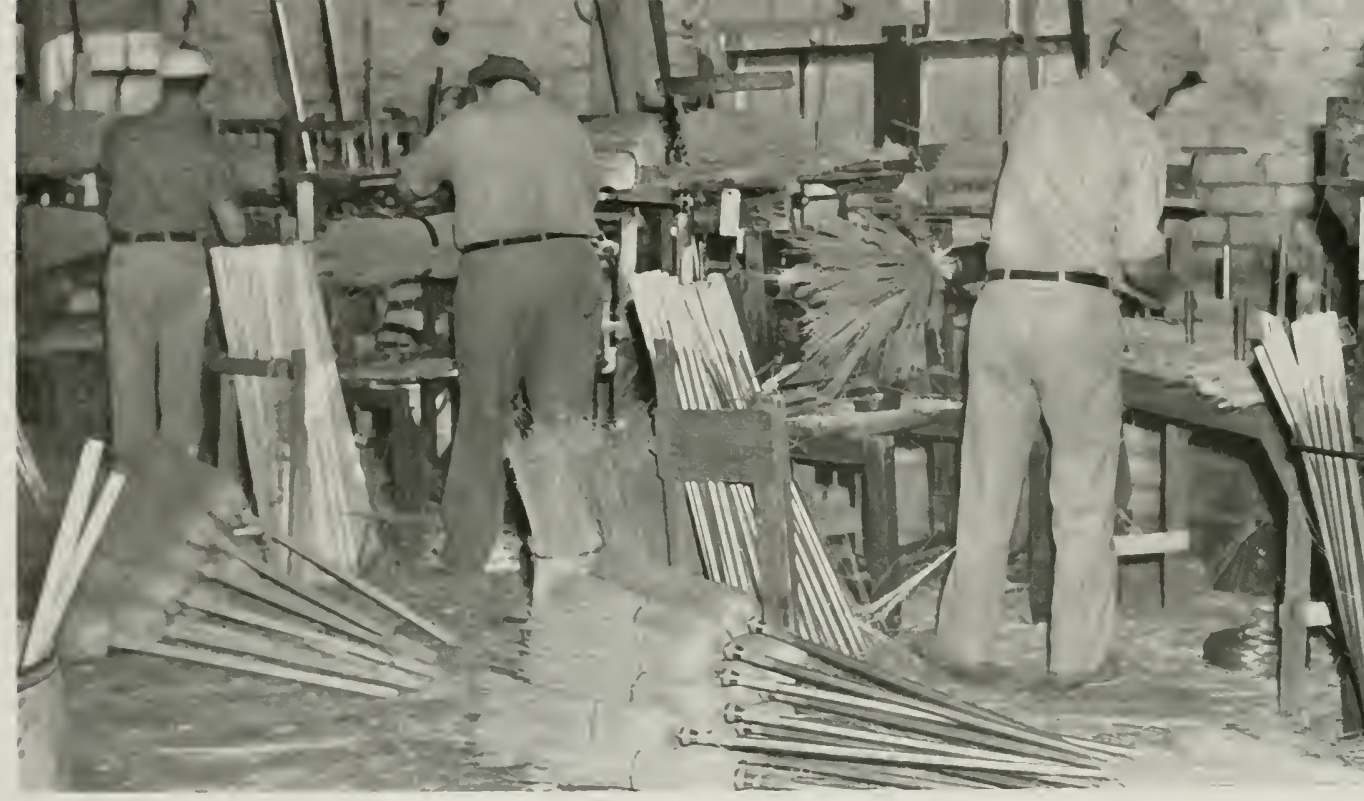

This is the winding operation in making a broom. Man at right is building up broom, using rough corn in center and better fibers on outside. A broom is appraised for its weight, which depends on the knack and feel of the man making it. 


\section{The Stary of Broomearn}

to handle and broom is ready for the next process. It usually goes then to a revolving cylinder and straws are evened up and any remaining seeds takel off and the looks improved in general. Then to the press and the sewing either by hand or by machine. The press shapes the broom in the iron viselike grips and holds it to the shape you receive it, while a man or a machine sews a seam of heavy flax thread through and through the body of the broom. The press is raised and process repeated several times for a $3-4$ or 5 seam broom.

Now a few operations such as trimming the ends square, attaching the label, bunching them in dozens and sacking, complete our brooms and make them ready for our corner store and service to man.

The production of broomcorn seed is an important, although relatively small enterprise in Illinois. Less than a dozen seed growers in Illinois, principally in Douglas county, supply practically all the seed used in Illinois and in the Lindsay district of Oklahoma. Very little seed is saved by the western growers in Oklahoma, Colorado, Kansas or New Mexico.

Broomcorn grown for seed is left standing in the field until the seed is ripe and then harvested in the regular manner. When cured, the brush is threshed and baled for market. Due to standing in the field for a longer period, the brush usually is discolored and brings only about half the price of corn not grown for seed. About twenty-five bushels of seed may be expected from an acre of corn. One bushel of seed will sow about 20 acres.

Seed is grown for three standard varieties of corn-standard, western dwarf and whisk dwarf. Seven distinct varieties are known. Trade names for various types include Evergreen, Black Spanish (known as Black Jap), California Golden, Scarborough, Black Spanish Dwarf, which was developed by H. Z. O'Hair of Bushton, Illinois, and Japanese Dwarf. White Italian, a branch of the Evergreen variety, is grown extensively in Illinois.

We have tried to give you a short story of broomeorn raising and the manufacture of brooms. Our facts are based on our observations in Illinois of both operations and a lot of the material came through Mr. P. A. Lindenmeyer of Arcola, Editor of Brooms and Broomcorn News and Secretary-Treasurer of the National Broom Manufacturer's Association, and through the writings of Mr. Frank Collins, formerly of Arcola. I thank them deeply for their help.

THE MARTINS OF ROCKOMF 


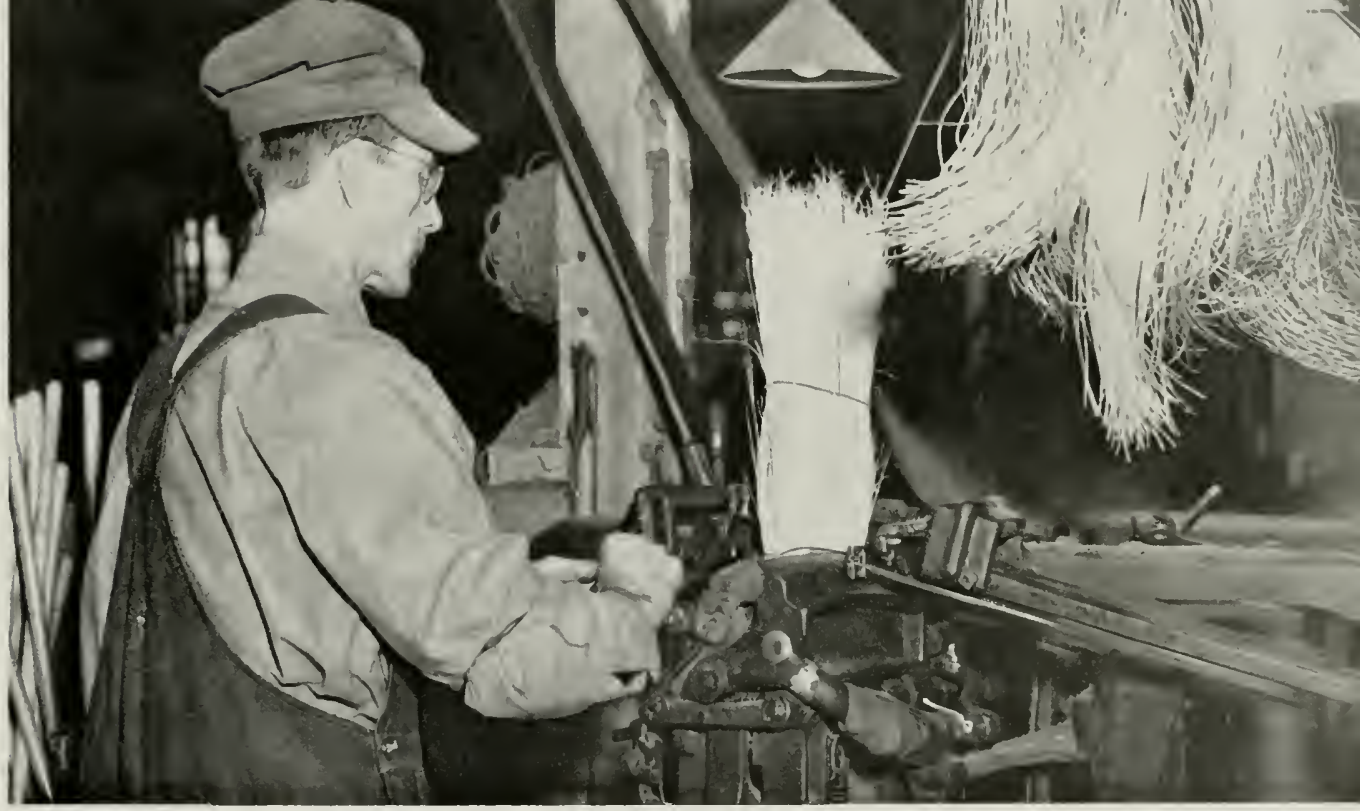

In the sewing operation shoulder of the broom is clamped into vice jaws. Four or five tiers of threads hold the fibers in place. This is one of many operations carried on in many factories in central eastern Illinois, principally in Tuscola, Arcola, and Mattoon. 


\section{Dedication...}

WEBSTER defines broomcorn as "a tall sorghum derived from Sorghum vulgare" and having "a jointed stem bearing a stiffbranched elongated panicle, used for making brooms and brushes".

But it means something more to scores of farmers in Douglas, Coles and Cumberland counties. It means cash income from a crop grown in no other section of Illinois.

To these industrious farmers who have grown broomeorn and the numerous factories in this

area which make brooms, we dedieate this booklet.

Mr and Mrs. Arthur Martin

ROCKOME

Arcola, Illinois 

UNIVERSITY OF ILLINOIS-URBANA

633. $1747 \mathrm{M} 363 \mathrm{~S}$ COO

THE SIORY OF BROOMCORN ARTHUR, ILL.

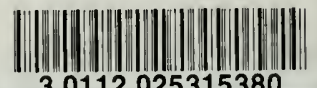
30112025315380 